\title{
Editorial characteristics and quality of the articles published by Brazilian Nursing journals
}

\author{
Características editoriais de produção e qualidade do produto \\ divulgado por revistas brasileiras de enfermagem \\ Características editoriales de producción y calidad del producto \\ divulgado por revistas brasileñas de Enfermería
}

Renata Perfeito Ribeiro',2, Maria Helena Palucci Marziale ${ }^{1}$

How to cite this article:

Ribeiro RP, Marziale MHP. Editorial characteristics and quality of the articles published by Brazilian Nursing journals. Rev Esc Enferm USP. 2018;52:e03367. DOI: http://dx.doi.org/10.1590/S1980-220X2017030003367

${ }^{1}$ Universidade de São Paulo, Escola de Enfermagem de Ribeirão Preto, Departamento de Enfermagem Geral e Especializada, Ribeirão Preto, SP, Brazil.

${ }^{2}$ Universidade Estadual de Londrina, Londrina, PR, Brazil.
Corresponding author:

Renata Perfeito Ribeiro

Av. Robert Koch, 60 - Vila Operária

CEP 86038-350 - Londrina, PR, Brazil perfeitorenata@gmail.com

\begin{abstract}
Objective: To analyze the editorial characteristics and the level of evidence of articles published by Nursing journals in Brazil. Method: Documentary research on the websites of five Nursing journals and analysis of the articles published in 2016, based on their level of evidence. The form used was validated by experts. Results: Editorial boards with Brazilian and foreign researchers, normalization and international ethical recommendations on the publications, online version with open access, continuous publication system (20.0\%), Portuguese and English, foreign authors (4.0\% to $14.7 \%)$. The information provided to the authors is not clear (20.0\%), articles with level of evidence $4(86.7 \%)$. The international community had access to some of the papers published, and the highest rates were JCR/WOS 0.6984, SJR/Scopus 0.396, H/Scopus index 26 and Google Scholar 30. Conclusion: Scientific journals follow international publication standards. Most of the articles published do not provide strong scientific evidence, which has an impact on the use of the knowledge, on the citations received and on the effective advancement of the knowledge of the area.
\end{abstract}

\section{DESCRIPTORS}

Periodicals; Publications for Science Diffusion; Scientific Communication and Diffusion; Evidence-Based Nursing; Journal Impact Factor. 


\section{INTRODUCTION}

Nursing is a profession recognized for the provision of care to people's health, with actions based on scientific knowledge resulting from research developed mainly by researchers in research groups and graduate programs, who have contributed to the significant advancement of the scientific knowledge of the area, making it possible to translate this knowledge into practice.

Scientific journals are the main vehicles for the dissemination of this knowledge, because they are effective in the propagation and in the speed of dissemination of the results obtained by researches.

The purpose of a scientific journal is to provide the community a channel for communicating and disseminating technical and scientific production through the publication of original articles. This dissemination broadens the knowledge of the specific area with the results of several researches, and contributes to the advancement of knowledge. A scientific journal should ensure quality and a high level of the articles published, and, as a consequence, guarantee citations to its articles in other scientific journals ${ }^{(1)}$.

In addition to disseminating knowledge, scientific journals give visibility to research advances, preserve memory, are educational sources and also have a social and political role in the scientific community.

Therefore, scientific journals must be composed of independent dimensions so that they can be indexed in a given database. These dimensions are: technical-normative (form); product purpose (content); quality of the productive process; and market quality. The technical-normative dimension presupposes the existence of standards, so the journal gains international visibility when it complies with international standards ${ }^{(2)}$.

According to the author mentioned, the product purpose (content) dimension should be clear in the editorial policy and mission of the scientific journal and is understood as recent publications relevant to the journal's target public. In this dimension, peer review, highly qualified and diversified editorial board and ad hoc consultants, with institutional scientific support are also indispensable.

The dimension quality of the productive process is associated with editorial procedures carried out in transparent, effective, efficient, complete and systematic way. Market quality is related to the quality that the consumer attributes to the journal. For the success of a journal, it must be indexed in databases and available on the Internet ${ }^{(2)}$.

The editorial policy and the requirements for the publication of articles are determinations that must be presented by the journal and be clear to the authors of scientific articles.

Among the editorial practices also evaluated by the indexing databases are integrity and good publication practices, which are based on the ethical aspects and transparency of the editorial process. The publication process should follow a set of criteria and roles of authors, editors, reviewers and service providers, both ethically and operationally, such as the protection and accuracy of research results, the publication of negative data or results contrary to the hypothesis determined in the beginning of the research and the declaration of sources of funding and conflicts of interest ${ }^{(3)}$.

Regarding the ethical aspects of research, the Committee on Publication Ethics (COPE) states that fabrication and falsification of data, omission of authors, plagiarism and self-plagiarism, duplicate publication, failure to obtain ethical approval by the Research Ethics Committee are serious infractions ${ }^{(4)}$. Therefore, these will be considered for lawsuit.

The index databases facilitate the disclosure of articles, and the main databases in the nursing area are considered in the Qualis-CAPES classification system - WOS bibliometric indices: Web of Science (WOS), National Library of Medicine (MEDLINE), SCImago (SCOPUS), Latin American and Caribbean Health Sciences Literature (LILACS), Cumulative Index to Nursing \& Allied Health Literature (CINAHL), CUIDEN, collections Scientific Electronic Library Online (SciELO), Nursing Journals Portal of the Virtual Health Library (Rev@Enf) ${ }^{(5-6)}$.

Another issue to be addressed is the levels of evidence that classify a scientific article, since the strength of evidence presented by the research method can be classified into levels ${ }^{(7)}$.

Given the context presented, we sought to answer the following research questions: What are the editorial characteristics of the nursing journals published in the country? What is the quality of the product? Therefore, the objective of this study was to analyze the editorial characteristics and the level of scientific evidence of articles published by nursing journals in Brazil.

\section{METHOD}

Documentary research based on the information available in the electronic websites of scientific nursing journals published in Brazil and the original articles and literature reviews published by them from January to December 2016.

The criteria used to select the journals for the sample were: journals classified as A1, A2 and B1 in the Qualis/ CAPES system in the nursing area, as published in $2015^{(5)}$. These criteria allow the analysis of articles in journals that received different classifications and that published the largest number of articles. Thus, the sample was composed of the following journals: Revista Latino-Americana de Enfermagem (RLAE), Revista da Escola de Enfermagem da USP (REEUSP), Acta Paulista de Enfermagem (ACTA), Revista Brasileira de Enfermagem (REBEN) e Texto e Contexto Enfermagem.

Data was collected from April to June 2017, through a form composed of questions related to the characteristics of the production: journal identification data, International Standard Serial Number (ISSN), mission, publication topics, bibliographical data, funding, national and foreign editorial board and if it is affiliated to Brazilian or foreign institutions, instructions to authors, periodicity, regularity, languages (summary, abstract and complete article), standards of reference, ethical standards, number and type of articles, nationality of the articles' authors, dissemination of the journal, last update of the website, article submission platform, indexing in databases, journal quality metrics in 
the database that performs its bibliometric analysis. These data were collected as described in the journal and in the footnotes of articles published, in addition to the classification of the level of evidence of the studies published and the journal metrics in the index databases.

The items evaluated in relation to the instructions to the authors were: editorial policy, article acceptance categories, review process, authorship policy, conflicts of interest, publication and submission fees, translation policies, languages of publication, preparation of articles for submission, ethical issues, good publication practices and integrity, open access licenses, clinical trial records, approval by the Research Ethics Committee, peer review, plagiarism detection tools, adoption of international standards in the presentation of articles, documents necessary for submission of articles and indication of funding.

In the preparation of the article by the author to submit to evaluation in the journals, the following items were considered: structure of the articles, name, academic title and nationality of each author, address of the corresponding author, formatting, title, abstract and descriptors of the article, name of each session of the article, formatting of tables, headings, footnotes, acronyms, figures, tables and graphs, citations in the text, reference models, need for shortened title and acknowledgments.

For the evaluation of the quality of the articles published, the classification of level of evidence according to the scale proposed by the Agency for Healthcare Research and Quality ${ }^{(7)}$ was used. According to this scale, Level 1 are meta-analysis of multiple controlled studies; Level 2 corresponds to individual studies with experimental design; Level 3 includes studies with quasi-experimental design, such as semi-randomized with single group, pre and posttest and case-control; Level 4 are non-experimental studies, such as correlation, descriptive and qualitative research with case study; Level 5 are systematic case reports with verified quality of program evaluation data; and Level 6 consists of expert opinions based on clinical competence, and expert committee opinions, including interpretations of investigative reports and law regulation opinion. A total of 663 articles published by the five journals in 2016 were analyzed for quality.

The data analyzed are primary sources, collected in the electronic websites of the journals and in the article submission platforms (ScholarOne administrative system).

Before the beginning of the data collection in scientific journals, the data collection form developed by the authors was sent to 16 scientific editors or associated editors, members of the Editorial Boards of nursing journals published in Brazil and indexed in the main databases. Scientific editors and associated editors, experts in the subject, who agreed to validate the instrument in relation to its objective and to the adequacy of the questions asked, signed a Consent Form and received the instrument by electronic mail.

After the first round of expert evaluation, which was performed by nine editors, the following adjustments were made: substitution of the word "online" for "electronic" in the question about how articles are published; substitution of the word "sponsors" for "funding" of the journal; and substitution of scale chosen to evaluate the evidence level of the studies, since the scale previously selected did not clearly state the level of evidence for qualitative articles. Thus, the scale proposed by the Agency for Healthcare Research and Quality ${ }^{(7)}$ was adopted. After the adjustments, the form was sent back to the experts for analysis. All the experts agreed with the reformulations, and the form was considered ready to be used.

Data analysis was performed based on descriptive and analytical statistics, with simple and absolute frequency calculations.

All ethical standards were met according to Resolution No. 466/12 of the National Health Council, which approves guidelines and regulatory standards for research involving human beings ${ }^{(8)}$. This project was approved in 2016 by the Research Ethics Committee of the Nursing School of Ribeirão Preto - USP, under the protocol 1.816.591 and CAAE 588 12616.7.0000 5393.

\section{RESULTS}

Regarding the characterization of the nine editors who evaluated the data collection instrument, the majority were female (62.5\%), aged between 50 and 65 years, all had $\mathrm{PhD}$ and half of them had postdoctoral experience (50.0\%). Most had teaching experience (88.9\%), and were working as editors for a period of 4 to 10 years $(75.0 \%)$ and had training and expertise in publishing (75.0\%). One of the editors did not respond to the characterization questions in the instrument validation process.

Regarding the analysis of the journals' editorial production, two journals did not present the name of the scientific editor, which was presented along with the associated editors of the journal. All journals use the ScholarOne submission system and are available in electronic format. The number of articles published in the year 2016 by the five journals totaled 663 studies. One of the journals adopts the Rolling Pass system since 2016, and another has adopted it since 2017. Those who have not adopted this system publish articles every two or three months.

Table 1 presents the language of the summary, the abstract and the scientific article, the area of publication and the indexing databases of the scientific journals evaluated in this study.

In the instructions to the authors, $20.0 \%$ of the journals did not clarify the article translation policy, the languages of publication, the use of a plagiarism detection tool and the documents required for article submission, $20.0 \%$ did not specify the categories of articles accepted for publication, authorship policy and the use of open access licenses, 20.0\% did not express the obligatory use of clinical trial records and the need for international standards for the presentation of articles, and $20.0 \%$ did not explain the use of plagiarism detection tools.

In the preparation of the articles for the analysis of a possible publication, $20.0 \%$ did not specify where to include acknowledgments, $20.0 \%$ did not express the need for an abbreviated title or where to include acknowledgments, and $60.0 \%$ did not present the need for an abbreviated title. 
Table 1 - Language of summary, abstract and scientific article, area of publication and indexing databases of scientific journals - Brazil, 2016.

\begin{tabular}{lccc}
\hline Languages of Publication & English (\%) & Portuguese (\%) & Spanish (\%) \\
\hline Summary & 40.0 & 100.0 & 40.0 \\
Abstract & 80.0 & 80.0 & 60.0 \\
Complete article & 100.0 & 100.0 & 60.0 \\
\hline Area of publication & Nursing and Health (\%) & Nursing (\%) & 40.0 \\
\hline & 60.0 & & \\
Indexing Bases & $\%$ & & \\
\hline WOS & 40.0 & \\
SCOPUS & 40.0 & \\
PubMed & 40.0 & \\
BDenf & 40.0 & \\
SCIELO & 40.0 & & \\
\hline
\end{tabular}

Regarding the norms adopted for the publication of articles, $60.0 \%$ adopted the Vancouver system, and $40.0 \%$ did not specify which standard should be adopted in the scientific articles.

All the journals analyzed had a website in Portuguese, English and Spanish, updated, with open access, containing the mission of the journal, ISSN, funding, periodicity of publication, editorial board, and presented the council of editors, the board of directors, the editorial board, and the technical team of the journal.

Table 2 presents the nationality of the editorial board and of the authors who published articles in the scientific journals studied in the year 2016 .

Table 2 - Mean of Nationality of the editorial board and authors in the scientific journals studied - Brazil, 2016.

\begin{tabular}{lccc}
\hline Nationality & $\begin{array}{c}\text { Brazilians } \\
(\%)\end{array}$ & $\begin{array}{c}\text { Foreigners } \\
(\%)\end{array}$ & $\begin{array}{c}\text { Brazilians/ } \\
\text { Foreigners (\%) }\end{array}$ \\
\hline $\begin{array}{l}\text { Editorial Board } \\
\begin{array}{l}\text { Authors of } \\
\text { Articles }\end{array}\end{array}$ & 52.8 & 47.2 & - \\
\hline
\end{tabular}

All journals publish articles related to their mission. The topics covered by the articles were: health care, nursing care, health/nursing research, human resources in health/nursing, health/nursing education, occupational health, organization and management, and technology.

Table 3 shows the level of scientific evidence of the articles published in the scientific journals analyzed in this study.

Table 3 - Quality of the articles evaluated according to level of evidence - Brazil, 2016.

\begin{tabular}{lcc}
\hline Level of Evidence* & Level of Evidence & $\%$ \\
\hline Level 1 & Meta-analysis of multiple & $1.2 \%$ \\
Level 2 & Controlled studies & Experimental Designs \\
Level 4 & $4.7 \%$ \\
Level 5 & $\begin{array}{c}\text { Descriptive correlational } \\
\text { studies and qualitative studies }\end{array}$ & $86.7 \%$ \\
\hline
\end{tabular}

*Agency for Healthcare Research and Quality.
The analysis of the journal quality metrics found that in the Journal Citation Reports /Web of Science (JCR/WOS) the highest index among the journals is 0.6984 , in the Scientific Journal Rankings (SJR) it is 0.396, in the H index Scopus it is 26 and in the Google Scholar it is 30 . The journal best classified in international ranking is in the 94 th $^{\text {position }}{ }^{(9)}$.

\section{DISCUSSION}

The purpose of scientific journals is to disseminate articles that may contribute to the advancement of science. To do this, they must present quality criteria for the dissemination of knowledge, train authors and reviewers to improve the quality of research and clearly present these regulations to readers.

The journals that have a renowned Editorial Board, good reviewers and a strict peer review process can select good quality articles and gain more prestige in the scientific community. A relevant aspect is that technical and operational issues should be managed systematically through a transparent and efficient process, guided by editorial policy and the journal's standards.

The journal's standards include the following aspects: journal formatting, instructions to authors, description of the areas of interest of the journal, sections, standards adopted, with examples to be followed by the authors, responsibility of content and copyright ${ }^{(10)}$.

Some criteria are established by specific databases and/ or journal collections in order to index the journals, and the strictness of these criteria depends on the purpose of the database and is related to prestige in the academic community. However, the common criteria in all databases are: scientific level or quality of the articles, current relevance of the topic, identification with the thematic areas of the journal, percentage of original articles, languages, notoriety and prestige of the members of the editorial board, national and international authors, forms of distribution and dissemination of the journal ${ }^{(10)}$. These criteria determine which journals can remain indexed, as well as those that can be included in those databases.

Indexing in databases makes the research results available to the national and international scientific community 
and gives visibility to journals and publications ${ }^{(6)}$. Therefore, indexing is necessary for a scientific journal to be read and recognized by the scientific community. This also allows the articles published by the journal to be cited and increases the visibility of the author.

The SciELO library requires that the journals indexed are also in international databases and maintain international standards for publishing ${ }^{(11)}$. This electronic library has been responsible for increasing the visibility of scientific production in the Nursing area.

Another important issue that editors of scientific journals and index databases must consider is the practice of plagiarism and self-plagiarism by the authors, which is often due to lack of knowledge or strong pressure to publish exerted by research funding agencies. Copying ideas is illegal and does not contribute to the growth of science.

This is an unethical practice that must be inhibited. For this, editors and reviewers of scientific journals must be encouraged to carefully read the articles submitted and adopt plagiarism detection tools. In addition, the journal must establish clear guidelines for authors ${ }^{(12)}$. It should be noted that higher education institutions that have scientific journals already adopt systematically the use of plagiarism detection tools.

Integrity in scientific research must be a prerequisite in all scientific journals. A study that aimed to analyze ethical standards adopted by scientific journals and to elaborate an ethics requirement score to evaluate criteria for ethics in scientific publication found that the Journal Impact Factor did not interfere in the Ethics Requirement Score ${ }^{(13)}$. It should be noted that index databases are strict with this aspect, removing from their list the journals that do not adopt the good publication practices recommended by the Declaration of Helsinki ${ }^{(3-4,14)}$.

The evaluation of the scientific production carried out by the index databases can be done with qualitative parameters, such as the peer review used by the journals, the publications and the results of research investments are measured by the scientific production and the use of bibliometric indicators ${ }^{(15)}$

There has been much discussion about the metrics and tools used to evaluate the quality of scientific journals, since the main index databases use scientometric indices and rank the journals according to the number of citations that each one obtained in a given period. However, these calculations are only performed on the publications of each index database for internal use. Nonetheless, these citation indices have been used by research funding agencies and education institutions to evaluate the performance of researchers, professors, students and graduate courses. Today, the most important index in the academic community regarding scientific journals is the Impact Factor produced by the WOS database ${ }^{(11)}$.

The WOS Impact Factor is published annually by JCR. The impact factor determines how often a particular article in a journal is cited, thus evaluating the journals included in the database ${ }^{(16)}$.

The number of citations received does not always indicate the actual quality of the article. In many cases, authors who cite other authors do not even understand the subject in depth to be able to discern between a good quality article and an inferior quality one.
The criteria for indexing journals in the WOS database are rigid and selective. The aspects evaluated by the database include regularity of publication, compliance with international publication standards, the peer review process, the presence of informational titles, the correction of the references cited, the adoption of ethical standards, presence of complete information, the quality and current relevance of articles, the dissemination of the journal and the indexing in national and international databases ${ }^{(10)}$

Another index that has gained prestige is the SCImago Journal \& Country Ranking (SJR), calculated in the Scopus database citations, which also presents the $\mathrm{H}$ index as a parameter to evaluate the quality of the articles published in that database ${ }^{(17)}$. The criteria of this database are also rigorous and similar to the criteria established to be indexed in the WOS.

Regarding the editorial board and the peer-reviewers, it is necessary to guarantee the quality of the board and consultants, who are national and international researchers ${ }^{(10)}$. Editors learn about the subject in different ways: $94 \%$ learn on a day-to-day basis, $46 \%$ learn from an experienced editor, and $43 \%$ from other editors ${ }^{(18)}$. Therefore, new editors must be trained by the most experienced.

The level of evidence of the articles published also represents a way of contributing to the advancement of evidence-based knowledge for decision-making in practice ${ }^{(19)}$. However, nursing does not yet have many publications with strong evidence level, that is, clinical studies with randomization of subjects to support evidence-based practice ${ }^{(19)}$.

This study demonstrated that the scenario of publications with a strong level of scientific evidence has improved. In addition, research with qualitative and observational methods cannot be underestimated, since they are important and necessary for the advancement of science.

The scientific journals evaluated have many positive points in relation to other journals that were not included in this study, for example: Classification A1 and A2 on the Qualis-CAPES system, indexing in databases with open access in Portuguese, English and Spanish, national and international circulation and peer-reviews. However, there is a lack of funding from the institutions with which these journals are associated and from research funding agencies.

The journals that are not yet at the Qualis A1 and A2 levels must search for indexing in databases with international circulation and invest in internationalization for a greater dissemination and a higher number of citations of the articles published. For this, it is essential to invest in researchers of these institutions in order to promote research with methodological approaches that provide strong scientific evidence, thus increasing citations of published articles and supporting changes in practice. Consequently, its authors can gain more scientific prestige.

It is necessary to discuss scientific productivity, evaluation systems, internationalization and the development of policies to improve national journals, which must maintain a balance between national and international publications, transparency in its publications, cooperation between researchers and decentralized investment and funding ${ }^{(17,20)}$. 
The limitations of this study refer to unavailability of bibliometric indicators on the websites of some scientific journals evaluated. This may have impaired the evaluation of other metrics. The availability of these indices can bring more visibility to national journals.

\section{CONCLUSION}

The journals meet international publication standards from the editorial point of view. However, most of the articles published do not provide strong scientific evidence, which may interfere with the use of the knowledge disseminated by them. This is expressed by the limited number of citations received, represented by the scientometric indices. These elements raise the need for an urgent reflection among those involved in Nursing research, both authors and readers, and for the elaboration of effective strategies to increase the advance of the scientific knowledge of the area.

\section{RESUMO}

Objetivo: Analisar as características editoriais de produção e o nível de evidência dos artigos publicados por revistas de Enfermagem editadas no Brasil. Método: Pesquisa documental nos sítios eletrônicos de cinco revistas de Enfermagem e análise dos artigos publicados em 2016, a partir da classificação do nível de evidência científica. O formulário foi validado por especialistas. Resultados: Comitês editoriais formados por pesquisadores brasileiros e estrangeiros, normalização e recomendação internacional de ética na divulgação, versão on-line com acesso aberto, sistema contínuo de publicação (20,0\%), português e inglês, autores estrangeiros (4,0\% a 14,7\%). As informações aos autores não são claras (20,0\%), artigos com nível de evidência 4 (86,7\%). A comunidade internacional consumiu parte do produto divulgado, e os índices mais elevados foram JCR/WOS 0,6984, SJR/Scopus 0,396, índice H/Scopus 26 e Google Scholar 30. Conclusão: As revistas científicas apresentam padrões internacionais de produção. A maioria dos artigos publicados não oferece forte evidência científica, o que interfere na utilização do conhecimento divulgado, nas citações recebidas e no efetivo avanço do conhecimento da área.

\section{DESCRITORES}

Publicações Periódicas; Publicações de Divulgação Científica; Comunicação e Divulgação Científica; Enfermagem Baseada em Evidências; Fator de Impacto de Revistas.

\section{RESUMEN}

Objetivo: Analizar las características editoriales de producción y el nivel de evidencia de los artículos publicados por revistas de Enfermería editadas en Brasil. Método: Investigación documental en los sitios electrónicos de cinco revistas de Enfermería y análisis de los artículos publicados en 2016, a partir de la clasificación del nivel de evidencia científica. El formulario fue validado por expertos. Resultados: Comités editoriales formados por investigadores brasileños y extranjeros, normalización y recomendación internacional de ética en la divulgación, versión en línea con acceso abierto, sistema continuo de publicación (20,0\%), portugués e inglés, autores extranjeros (4,0\% al 14,7\%). Las informaciones a los autores no son claras (20,0\%), artículos con nivel de evidencia (86,7\%). La comunidad internacional consumió parte del producto divulgado, y los índices más elevados fueron JCR/WOS 0,6984, SJR/Scopus 0,396, índice H/Scopus 26 y Google Scholar 30. Conclusión: Las revistas científicas presentan estándares internacionales de producción. La mayoría de los artículos publicados no ofrece fuerte evidencia científica, lo que interfiere en la utilización del conocimiento divulgado, en las citaciones recibidas y en el efectivo avance del conocimiento del área.

\section{DESCRIPTORES}

Publicaciones Periódicas; Publicaciones de Divulgación Científica; Comunicación y Divulgación Científica; Enfermería Basada en la Evidencia; Factor de Impacto de la Revista.

\section{REFERENCES}

1. Brofman PR. A Importância das publicações científicas. Cogitare Enferm. 2012;17(3):419-21

2. Trzesniak P. As dimensões da qualidade dos periódicos científicos e sua presença em um instrumento da área da educação. Rev Bras Educ [Internet]. 2006 [citado 2017 jun. 20];11(32):346-61. Disponível em: http://www.scielo.br/pdf/rbedu/v11n32/a13v11n32.pd

3. World Medical Association (WMA). Declaração de Helsinque. Princípios éticos para pesquisa médica envolvendo seres humanos [Internet]. Fortaleza; 2013 [citado 2017 jun. 28]. Disponível em: https://www.amb.org.br/_arquivos/_downloads/491535001395167888_ DoHBrazilianPortugueseVersionRev.pdf

4. Wager $\mathrm{E}$, Kleinert $\mathrm{S}$. Cooperation between research institutions and journals on research integrity cases: guidance from the Committee on Publication Ethics (COPE). Acta Inform Med. 2012;20(3):136-40.

5. Coordenação de Aperfeiçoamento de Pessoal de Nível Superior (CAPES). Plataforma Sucupira. Qualis Periódicos [Internet]. Brasília; CAPES; 2017 [citado 2017 jun. 29]. Disponível em: https://sucupira.capes.gov.br/sucupira/public/consultas/coleta/veiculoPublicacaoQualis/ listaConsultaGeralPeriodicos.jsf

6. Erdmann AL, Marziale MHP, Pedreira MLG, Lana FCF, Pagliuca LMF, Padilha MI, et al. Evaluation of scientific periodicals and the Brazilian production of nursing articles. Rev Latino Am Enfermagem [Internet]. 2009 [cited 2017 June 10];17(3):403-9. Available from: http://www. scielo.br/pdf/rlae/v17n3/19.pdf

7. Melnyk BM, Fineout-Overholt E. Making the case for evidence-based practice. In: Melnyk BM, Fineout-Overholt E, editors. Evidence-based practice in nursing \& healthcare: a guide to best practice. $2^{\text {nd }}$ ed. Philadelphia: Lippincot Williams \& Wilkins; 2005. p. 3-24.

8. Brasil. Ministério da Saúde; Conselho Nacional de Saúde. Resolução n. 466, de 12 de dezembro de 2012 . Dispõe sobre diretrizes e normas regulamentadoras de pesquisas envolvendo seres humanos [Internet]. Brasília; 2012 [citado 2017 jun. 29]. Disponível em: http://bvsms. saude.gov.br/bvs/saudelegis/cns/2013/res0466_12_12_2012.html

9. Jornal Citation Reports - JCR (Thomson Reuters). InCites Journal Citation Reports dataset updated [Internet]. 2017Journal Titles Ranked by Impact Factor. [cited 2017 jul 20]. Available from: https://jcr.incites.thomsonreuters.com 
10. Marziale MHP, Mendes IAC, Malerbo MB. Desafios em la divulgación del conocimiento cientifico de enfermería producido en Brasil. Index Enferm. 2004;13(47):75-8.

11. Marziale MHP, Mendes IAC. O fator de impacto das publicações científicas. Rev Latino Am Enfermagem. 2002;10(4):466-7.

12. Van Noorden R. Science publishing: the trouble with retractions. Nature. 2011;478(7367):26-8.

13. Santos LG, Costa e Fonseca AC, Bica CG. Escore de exigência ética: nova ferramenta para avaliação da ética em publicações. Einstein (São Paulo). 2014;12(4):405-12.

14. Rosenberg J, Bauchner H, Backus J, de Leeuw P, Drazen J, Frizelle F, et al. The new ICMJE recommendations. Dan Med J. 2013;60(10):1-2.

15. Marziale MHP. Indicadores da produção científica ibero-americana [editorial]. Rev Latino Am Enfermagem [Internet]. 2011 [citado 2017 jun 10];19(4). Disponível em: http://www.scielo.br/pdf/rlae/v19n4/pt_01.pdf

16. Hirsch JE. An index to quantify an individual's scientific research output. Proc Nati Acad Sci U S A. 2005;102(46):16569-72.

17. Packer AL. Indicators of national focus of the research published by Public Health journals edited in Brazil. Ciênc Saúde Coletiva. 2015;20(7):1983-95.

18. Freda MC, Kearney M. An international survey of nurse editors' roles and practices. J Nurs Scholarsh. 2005;37(1):87-94.

19. Stetler CB, Brunell M, Giuliano KK, Morsi D, Prince L, Stokes VN. Evidence-based practice and the role of nursing leadership. J Nurs Adm. $1998 ; 28(7-8): 45-53$

20. Moseley ET, Hsu DJ, Stone DJ, Celi LA. Beyond open big data: addressing unreliable research. J Med Internet Res [Internet]. 2014 [cited 2017 June 10];16(11):e259. Available from: https://www.ncbi.nlm.nih.gov/pmc/articles/PMC4260008/ 